\title{
The recent history of the Galapagos Triple Junction preserved on the Pacific plate
}

Deborah K. Smith ${ }^{1}$, Hans Schouten ${ }^{1}$, Laurent Montési ${ }^{2}$, Wenlu Zhu ${ }^{2}$

${ }^{1}$ Department of Geology and Geophysics, Woods Hole Oceanographic Institution, Woods Hole, Massachusetts 02543, USA

${ }^{2}$ Department of Geology, University of Maryland, College Park, Maryland 20742, USA

\section{Corresponding author:}

Deborah K. Smith

email: dsmith@,whoi.edu

tel: $508-367-8578$ 


\section{Abstract}

At the Galapagos triple junction, the Cocos and Nazca plates are broken by a succession of transient rifts north and south of the Cocos-Nazca $(\mathrm{C}-\mathrm{N})$ Rift. Modeling has suggested that each rift initiated at the East Pacific Rise (EPR), its location controlled by the distance of the C-N Rift tip from the EPR. Evidence on the Pacific plate confirms that each transient rift formed a true RRR triple junction with the EPR and clarifies the history of the region. At $\sim 1.5 \mathrm{Ma}$ the triple junctions began jumping rapidly toward C-N Rift suggesting that the C-N Rift tip moved closer to the EPR. Pacific abyssal hills became broad and shallow indicating enhanced magma supply to the region. At $\sim 1.4 \mathrm{Ma}$, the Galapagos microplate developed when extension became fixed on the southern transient rift to form the South scarp of the future Dietz rift basin. Lavas flooded the area and a Galapagos-Nazca magmatic spreading center initiated at the EPR. We suggest that a hotspot was approaching the southern triple junction from the west. The hotspot crossed to the Nazca plate $1.25 \mathrm{Ma}$. Dietz seamount formed within the young spreading center, dikes intruded Dietz rift basin, and eruptions built volcanic ridges. Since $\sim 0.8$ Ma magmatic spreading has jumped northward twice, most recently to Dietz volcanic ridge. Amagmatic extension to the east has formed the large North scarp of Dietz rift basin. Northward jumping of the southern triple junction has maintained the microplate boundary close to the proposed hotspot.

Keywords: Galapagos triple junction; Galapagos microplate; crack interaction model; hotspot 


\section{Introduction}

At the Galapagos triple junction the tip of the Cocos-Nazca Rift (C-N Rift) is located $\sim 25 \mathrm{~km}$ east of the East Pacific Rise (EPR). Two secondary rifts link with the EPR to form ridge-ridgeridge (RRR) triple junctions (Figure 1). One rift is south of the C-N Rift at $1^{\circ} 10^{\prime} \mathrm{N}$ where Dietz volcanic ridge intersects the EPR, and a second one is to the north at $2^{\circ} 40^{\prime} \mathrm{N}$ where Incipient Rift intersects the EPR (e.g., Klein et al., 2005; Lonsdale, 1988; Lonsdale et al., 1992). Northeast of Incipient Rift, Schouten et al. (2008) identified a succession of older rifts and suggested that Incipient Rift is only the latest of a sequence of southeast-trending rifts that jumped southward and westward during the last $5 \mathrm{Ma}$, each accommodating some minor extension of EPRgenerated crust. Schouten et al. (2008) used a crack interaction model to explain the occurrence of these transient rifts and their triple junctions. In the model, the locations of secondary cracks are controlled by stresses generated by two major interacting cracks: one representing the tip of the large, westward propagating C-N Rift and the other the north-south trending EPR. The model shows a zone of reduced tension (compression) at the EPR in front of the C-N Rift preventing it from connecting to the EPR. Tensile stress maxima develop at the EPR north and south of the C$\mathrm{N}$ Rift tip facilitating the formation of cracks initiating at the EPR.

Currently the two triple junctions are not symmetric about the C-N Rift. The Galapagos microplate has formed south of the C-N Rift (Lonsdale, 1988; Searle and Francheteau, 1986; Zonenshain et al., 1980), and a triple junction is located at its southern boundary. Southeast of the microplate on crust older than 1.4 Ma, however, Smith et al. (2011) documented a succession of transient rifts, which are a mirror image of the rifts on the same age crust north of the C-N Rift. This band of southern rifts provides strong support for the applicability of the crack interaction model of Schouten et al. (2008) prior to 1.4 Ma. South of the C-N Rift, transient rifts are observed on seafloor as old as 10.5 Ma suggesting that the tip of the C-N Rift has not connected to the EPR in a simple RRR geometry since that time.

In this paper, we present newly identified evidence on the Pacific plate that confirms that each of the transient rifts was connected with the EPR and formed a true RRR triple junction. Using the trace of the southern triple junction on the Pacific plate, in combination with seafloor features on both the Pacific and Nazca plates, we also examine the establishment of the southern boundary of the Galapagos microplate. Finally, we investigate the recent history $(<1.5 \mathrm{Ma})$ of the Pacific-Galapagos EPR, the portion of the EPR between the two triple junctions, and its response to the nearby $\mathrm{C}-\mathrm{N}$ rift tip, the jumping triple junctions, and a proposed hotspot.

\section{Background - Identifying paleo triple junctions on the Cocos and Nazca plates}

Schouten et al. (2008) used the seafloor morphology of Incipient Rift - the current rift that makes a triple junction with the EPR at $2^{\circ} 40^{\prime} \mathrm{N}$ - to identify older rifts and their triple junctions. They suggested that Incipient Rift initiated at the EPR $\sim 0.5 \mathrm{Ma}$, extended southeast into the older Cocos plate and cut pre-existing abyssal hill topography. As the EPR spread, Incipient Rift maintained connection with the EPR and a broad volcanic high was built at its western end. Northeast of Incipient Rift, there are numerous other volcanic highs and associated cracks with similar strikes as Incipient Rift (southeast-northwest). These volcanic highs terminate against north-south-oriented EPR abyssal hills and based on their similarity to Incipient Rift, Schouten et al. (2008) inferred that they represent older rifts that had once intersected the EPR as Incipient Rift does today. 
The strike of the trace of the northern paleo triple junctions on the Cocos plate varies considerably (Figure 1). Schouten et al. (2008) suggested that a more westerly trend implies a relatively stationary triple junction, and a southerly trend implies that rifting and triple-junction volcanism jumped south rapidly and repeatedly. They suggested that when the tip of the C-N Rift moves closer to the EPR, the transient rifts jump rapidly south, and when the tip remains stationary with respect to the EPR, the transient rifts are stable growing westward as they maintain contact with EPR. Mitchell et al. (2011) expanded on the Schouten et al. (2008) model to show how a sequence of rapidly jumping rifts and triple junctions could form.

Southeast of the Galapagos microplate, Smith et al. (2011) documented numerous southwestnortheast oriented rifts, with similar morphology to the transient rifts north of the C-N Rift, and concluded that each rift also initiated at the EPR and extended east/northeast cutting pre-existing abyssal hill topography on the Nazca plate. These rifts formed simultaneously with the rifts on the Cocos plate north of the C-N Rift. Between about 2.5 and $1.5 \mathrm{Ma}$, the trace of the triple junctions in the southern area closely matches that in the northern area (Figure 2). The change in strike of the trace of the triple junctions from westerly to southerly toward the C-N Rift in the northern area is matched in the southern area (in this case from westerly to northerly) at about 1.5 Ma suggesting that the tip of the C-N Rift moved closer to the EPR at that time. Although the rapid jumping of rifts toward the $\mathrm{C}-\mathrm{N}$ Rift continued in the northern area until about $1 \mathrm{Ma}$, the jumping of the transient rifts in the southern area appears to have ceased around 1.4 Ma when the large South scarp of Dietz rift basin was established.

\section{Transient triple junctions recorded on the Pacific Plate}

Schouten et al. (2008) and Smith et al. (2011) interpreted the western ends of the transient rifts as extinct triple junctions with the EPR. If their interpretation is correct, the trace of the triple junctions should be preserved on the Pacific plate. To search for the triple junction traces we used the multibeam bathymetry map of Smith (2011). We observe that at the current northern triple junction (Figure 3a), the Pacific-Cocos EPR and Pacific-Galapagos EPR meet at an angle of $\sim 12^{\circ}$. At the southern triple junction (Figure 3b), the Pacific-Galapagos EPR and Pacific-Nazca EPR meet at an angle of $\sim 32^{\circ}$. These angles, which vary through time, are preserved off-axis in the abyssal hill topography and can be identified in the bathymetry.

Figures 2 and 3 display the paleo triple junction traces that we identified on the Pacific plate. The northern trace identified by Schouten et al. (2008) on the Cocos plate matches the trace on the Pacific plate extremely well. In the south, data are more limited. Nonetheless, where there are data the fossil triple junctions are well-defined. The identification of both triple junction traces on the Pacific plate validates the hypothesis that the secondary rifts formed true RRR triple junctions with the EPR north and south of the C-N Rift.

Opening rates on the transient rifts can be estimated by constructing plate velocity triangles based on the azimuth of the transient rift and the Pacific abyssal hill orientations at the paleo triple junction. The plate velocity triangles rely heavily on the assumption that spreading direction is orthogonal to abyssal hill and transient rift orientations, and that spreading is symmetric on all rifts. Also, it is assumed that both the Pacific-Cocos and Pacific-Nazca spreading rates have been constant for the last $3 \mathrm{Ma}$. Given these assumptions and using spreading rates from DeMets et al. (1994), the transient rift opening rates are related to the angle at which the Pacific-Galapagos EPR meets the Pacific-Cocos and Pacific-Nazca EPR axes at the triple junctions. Examples of the angles at various locations along the triple junction trace are 
shown in Figure 3. In the north, estimated opening rates on the transient rifts range between 40 and $12 \mathrm{~mm} / \mathrm{yr}$ for the largest $\left(17^{\circ}\right)$ and smallest $\left(5^{\circ}\right)$ angles measured, respectively. For reference, the C-N Rift opens at $42 \mathrm{~mm} / \mathrm{yr}$. At the current triple junction, the opening rate of Incipient Rift is estimated to be $28 \mathrm{~mm} / \mathrm{yr}$, which is larger than the $15 \mathrm{~mm} / \mathrm{yr}$ estimated by Lonsdale (1988).

In the south, estimates of opening rates on the extinct transient rifts range between 83 and 30 $\mathrm{mm} / \mathrm{yr}$ for the largest $\left(38^{\circ}\right)$ and smallest $\left(13^{\circ}\right)$ angles at which the EPR-generated abyssal hills meet. Near the current southern triple junction, we estimate the opening rate of the GalapagosNazca boundary to be $71 \mathrm{~mm} / \mathrm{yr}$, again larger than the $40 \mathrm{~mm} / \mathrm{yr}$ value of Lonsdale (1988). Our opening rates appear to be too high given that Smith et al. (2011) concluded that the transient rifts preserved on the Nazca and Cocos plates are graben bounded by small-offset normal faults that had only minor extension. We conclude that the angles at which the north and south limbs of the EPR meet at the triple junctions do not reflect plate motions. Instead, they must reflect a different process, which we consider in Section 5.

\section{The southern boundary of the Galapagos microplate}

Symmetry in cracking north and south of the tip of the C-N Rift breaks down with the establishment of the Galapagos microplate about 1.4 Ma. Within the western section of the Galapagos-Nazca boundary two large seamounts and Dietz volcanic ridge have been constructed. The southernmost seamount (Dietz seamount, Figure 4a) is nearly $2 \mathrm{~km}$ high. The $65-\mathrm{km}$-long Dietz volcanic ridge has a relief of up to $1 \mathrm{~km}$ in places, and $15 \mathrm{~km}$ from the triple junction the ridge is about $200 \mathrm{~m}$ shallower than the EPR. Because of the large volume of lava that has been erupted to build these features, we assume that a nearby hotspot is currently located beneath the Nazca plate.

The extensive volcanism has made the identification of the $<1.4 \mathrm{Ma}$ triple junction trace on the Nazca plate difficult, but in combination with the record on the Pacific plate the history of the Galapagos microplate can be pieced together (Figures 2 and 4). Just prior to $1.4 \mathrm{Ma}$, the pattern of transient rifting in the south mirrored that in the north. Both the northern and southern rifts were jumping rapidly toward the $\mathrm{C}-\mathrm{N}$ Rift. At about $1.4 \mathrm{Ma}$, jumping stopped in the south while jumping in the north continued until 1.0 Ma. Since $1.4 \mathrm{Ma}$, two consecutive wedges of magmatic seafloor have formed at the southern triple junction (V1 and V2 on Figure 4b). We suggest that each of their tips connected to the EPR to form a stable triple junction. The shapes of the wedges yield average spreading rates and directions of $39 \mathrm{~mm} / \mathrm{yr}$ at $158^{\circ}$ for $\mathrm{V} 1$ and 33 $\mathrm{mm} / \mathrm{yr}$ at $144^{\circ}$ for V2 (Figure 4c), which implies about $50 \mathrm{~km}$ of northwest-southeast extension on average for the Galapagos-Nazca boundary since $1.4 \mathrm{Ma}$. The shapes of the wedges also predict Pacific-Galapagos spreading directions of $80^{\circ}(\mathrm{V} 1)$ and $85^{\circ}$ (V2) that are compatible with the appropriate Pacific-Galapagos abyssal hill orientations. V1 was active from about 1.4 to 0.8 $\mathrm{Ma}$ after which rifting jumped north and spreading began on V2. Very recently ( 0.1 Ma), V2 was abandoned and rifting and the triple junction jumped rapidly north to Dietz volcanic ridge and appears to have been stable since then.

Dietz rift basin makes up the eastern section of the Galapagos-Nazca boundary (Lonsdale, 1988), and extends close to the scarps of the C-N Rift. Hydrophone-recorded seismicity (Fox et al., 2001) shows that Dietz rift basin is actively extending (Figure 4b). Earthquakes are located primarily near the large North scarp of the rift basin, and available focal mechanisms obtained from the Global Centroid-Moment-Tensor (CMT) Project (http://www.globalcmt.org/) indicate northwest-southeast extension in that region. (We currently cannot explain the focal mechanisms 
showing east-west extension near the large seamounts.) Volcanic ridges $20 \mathrm{~km}$ or more in length extend into Dietz rift basin and suggest that diking accommodated some of the extension. The north-facing slope of the basin's large North scarp is covered by lavas which continue northward to cover lineations on the Galapagos microplate (Figure 4a) and we presume that the lavas were erupted in the early magmatic phase of opening of the rift basin.

A puzzling region of what appears to be rapidly jumping rifts starting about $0.2 \mathrm{Ma}$ is observed north and west of Dietz volcanic ridge. A sequence of volcanic ridges oriented northwest-southeast (labeled NW-SE ridges on Figure 4a), and having similar morphology to the western ends of the transient rifts observed on the Cocos plate, end abruptly at north-south trending abyssal hill topography. We do not have an explanation for these features unless Dietz volcanic ridge was disconnected from the EPR producing a small scale version of the stress field generated by the large, disconnected C-N Rift. The intersections of these possible rifts with the EPR, however, have not been identified on the Pacific plate and thus, probably did not form true RRR triple junctions.

\section{The Pacific-Galapagos EPR}

At $1^{\circ} 50^{\prime} \mathrm{N}$, the Pacific-Galapagos EPR has a $15 \mathrm{~km}$ east-west offset (Figure 5), and Lonsdale (1989) suggested that there have been several episodes of migrating offsets along the PacificGalapagos EPR in the recent past. The record on the Pacific plate indicates that the most recent migration began at the northern triple junction about $0.6 \mathrm{Ma}$. Southward propagation of the eastern limb of the axis produced a right-stepping offset in the axis. As the offset migrated south plateaus of rotated crust were produced between the overlapping limbs of the EPR (Lonsdale, 1989). The plateaus are now part of the Pacific plate (Figure 5). A similar sequence of rotated plateaus is observed farther off-axis, suggesting there was an earlier episode of southward migration of a ridge axis offset $(\sim 1 \mathrm{Ma})$, which also started at the northern triple junction.

The Pacific-Nazca EPR and the Pacific-Cocos EPR show the morphology of a typical fastspreading ridge: an axial high 2-4 km wide with relief of a few hundreds of meters (Figure 6). The Pacific-Galapagos EPR is much more complex. From the northern triple junction south to the offset at $1^{\circ} 50$ ' $\mathrm{N}$, the axial region gradually deepens from about $3000 \mathrm{~m}$ to $3300-3400 \mathrm{~m}$. And instead of an axial high, the EPR axis has horst and graben morphology more typical of a slowspreading ridge (Figure 6). Relief on axis-facing normal faults is a few hundreds of meters, in some places reaching $400 \mathrm{~m}$. Immediately south of the offset, the EPR is broad ( $\sim 10 \mathrm{~km}$ wide) and composed of three ridges, the shallowest of which rises to about $2800 \mathrm{~m}$ water depth.

The abyssal hills preserved on the Pacific plate west of the Pacific-Galapagos EPR on crust $>1.5 \mathrm{Ma}$ have a similar shape as abyssal hills on the same age crust west of the Pacific-Cocos and Pacific-Nazca EPRs. On crust $<1.5 \mathrm{Ma}$, however, the abyssal hills west of the PacificGalapagos EPR are broader and shallower (profile on Figure 5) and are convex to the west in plan view. Because, abyssal hills of the same age on the east side of the axis have not been preserved, it is difficult to determine whether the increase in heights and widths reflect enhanced magma supply off- or on-axis. We think, though, that the convex west shape indicates that the northern and southern ends of the axis bent eastward toward the EPR. We suggest that the bending allowed the axis to maintain contact with the triple junctions that were jumping toward the C-N Rift after a period of relative triple junction stability. At $\sim 1.0 \mathrm{Ma}$, a right-stepping offset of the EPR migrated south from the northern triple junction. The migration of the offset southward was rapid ( $\sim 150 \mathrm{~mm} / \mathrm{yr})$ and straightened the northern section of the Pacific- 
Galapagos axis. Subsequently, the axis again became convex west in plan shape. The most recent southward migration of a right-stepping offset of the EPR from the northern triple junction occurred at $\sim 0.6 \mathrm{Ma}$, and it both straightened the axis and led to the development of horst and graben topography in the axial region.

\section{Discussion}

A succession of transient, east-west trending rifts north and south of C-N Rift at the Galapagos triple junction, has been explained by a simple crack interaction model (Mitchell et al., 2011; Schouten et al., 2008). The rifts initiate at the EPR and their locations at the EPR are controlled by tensile stresses generated by two major, interacting cracks: one crack representing the north-south trending EPR, and the other the large, westward propagating C-N Rift, whose tip does not meet the EPR. Two newly identified triple junction traces on the Pacific plate, one north and one south of the projected tip of C-N Rift, provide strong evidence that the transient rifts formed RRR triple junctions with the EPR, and reaffirm the idea that the rifts on the Cocos and Nazca plates could be generated by stresses associated with the tip of the propagating C-N Rift as predicted by the crack interaction model.

The crack interaction model also predicts symmetric rifting north and south of the C-N Rift tip. Symmetry in rifting is observed and especially remarkable between 2.5 and 1.5 Ma (Smith et al., 2011). In fact, at 1.5 Ma the rapid jumping of the rifts and their triple junctions toward the C$\mathrm{N}$ Rift in both the northern and southern regions appears synchronous. The synchronous jumping can be explained by the tip of the C-N Rift moving closer to the EPR, causing the two tensile stresses at the EPR to move closer to the rift tip. Breakdown in symmetry of cracking at $\sim 1.4$ Ma occurred when the southern transient rift stopped jumping northward and became the southern boundary of the Galapagos microplate.

The trace of the triple junctions identified on the Pacific plate together with seafloor features on the Pacific and Nazca plates help to elucidate the recent history of the southern triple junction. We assume that the excess volcanism observed along the southern boundary of the microplate is related to a hotspot, and that the hotspot produced Dietz seamount $\sim 1.2 \mathrm{Ma}$ and may be responsible for the anomalous elevation $(\sim 1 \mathrm{~km})$ of the current Dietz volcanic ridge. We use relative plate motions from NUVEl-1A (DeMets et al., 1994) and absolute plate motions from HS3-NUVEL-1A (Gripp and Gordon, 2002) to investigate the movement of this proposed hotspot (Figure 7) and its possible effect on the southern triple junction region. It is important to note though that large variations in estimated plate velocities exist between the different plate motion models that are available. For example if we had chosen the MORVEL model (Argus et al., 2011; Bird, 2003), absolute velocity of the Pacific plate would decrease by nearly 50\% and the absolute velocity of the Nazca plate would increase nearly 5-fold. The following scenario, shown schematically in Figure 8, depends heavily on our choice of plate velocity models as well as the estimated 1.2 Ma age of Dietz seamount.

We suggest that before 1.4 Ma, a hotspot was approaching the southern triple junction from the west $\left(\sim 41 \mathrm{~km} / \mathrm{my}, 97^{\circ}\right)$. As the hotspot got close to the axis, northward jumping of the rifts stopped and extension became fixed on the southern 1.4 Ma rift. Between about 1.4-1.25 Ma, extension on the 1.4 Ma crack led to the formation of the South scarp of the future Dietz rift basin. Lavas flooded a large area north of this scarp, and magmatic spreading between Nazca and Galapagos began at the triple junction at an average rate of $\sim 39 \mathrm{~mm} / \mathrm{yr}$ (V1 on Figures 4, 7, and 8). The hotspot crossed from the Pacific to the Nazca plate (Figures 7 and 8) at about 1.25 Ma, 
and since then has moved westward $\left(285^{\circ}\right)$ with respect to the Nazca plate at $21 \mathrm{~km} / \mathrm{my}$. At 1.2 Ma, shortly after the hotspot crossed to the Nazca plate, Dietz seamount began to form over the hotspot and within the young Nazca-Galapagos spreading center near the triple junction; a system of dikes was emplaced into Dietz rift basin accommodating extension and volcanic ridges several hundreds of meters high were constructed. Around 1.0-1.1 Ma the original Dietz seamount was split apart by spreading on V1. We are not sure how long the northern section of the seamount remained active since it is now riddled by faults, but Dietz seamount remained active with eruptions forming a circular, flat-topped volcano rising to water depths of less than $1600 \mathrm{~m}$.

At about $0.8 \mathrm{Ma}$, magmatic spreading jumped northward to V2, which had an average opening rate of $\sim 33 \mathrm{~mm} / \mathrm{yr}$ (Figures 7 and 8 ). Amagmatic extension in the east led to the development of the North scarp of Dietz rift basin. The northward facing slope of the North scarp is covered by lava flows, suggesting that the fault cut through crust that had been flooded by earlier lavas. Linking of the magmatic (western) and amagmatic (eastern) sections of the V2 boundary has led to severely fractured seafloor features in and around Dietz rift basin including the fractured northern section of Dietz seamount as mentioned above. Most recently $(\sim 0.1 \mathrm{Ma})$, magmatic spreading jumped northward to Dietz volcanic ridge. Current seismicity (Figure 4) indicates that extension is focused on the North scarp of Dietz rift basin.

In general, plate motions dictate that the newly established southern triple junction should migrate south, and it has done so during magmatic spreading events V1 and V2, and recently since Dietz volcanic ridge became the new magmatic spreading center (Figures 7 and 8). The northward jumps of the Galapagos-Nazca spreading center at 0.8 and 0.1 Ma maintain its location west of the proposed hotspot and thus, we suggest that the location of the southern boundary of the microplate is controlled by the hotspot. The shallowest point of Dietz volcanic ridge is close to the proposed current location of the hotspot suggesting it is being fed by hotspot magmatism.

As recorded in the abyssal hill topography on the Pacific plate, the shape of the PacificGalapagos EPR changed at $\sim 1.5 \mathrm{Ma}$ at the same time that the transient triple junctions began jumping rapidly toward C-N Rift. We hypothesize that to maintain contact with the jumping triple junctions, the north and south ends of the Pacific-Galapagos EPR bent eastward creating a convex-west shaped ridge axis in plan view and requiring oblique spreading near the triple junction. Two migrating offsets nucleated at the northern triple junction, one at about $1.0 \mathrm{Ma}$ and the other about 0.6 Ma. The southward migration of the right-stepping offsets straightened the northern section of the Pacific-Galapagos EPR to produce a more stable configuration of the axis (e.g., Wilson et al., 1984). The most recent migration has deepened the axis significantly, perhaps because the offset between the two limbs of the EPR was large enough that the eastern limb propagated south into colder, off-axis crust. Immediately south of the northern triple junction the axis looks as if it may be reestablishing itself to an axial high (Figure 6).

The two episodes of southward migrating EPR offsets are marked by trails of rotated plateaus. Offset migration at the fast-spreading EPR typically leaves deeps with rotated structures within them or trails of seamounts in their wake (e.g., Lonsdale, 1989). The plateaus may reflect enhanced magma supply to the axis such as indicated by the broad, shallow character of the retreating limb of the EPR observed at the current overlap. The abyssal hills on Pacific 
crust $<1.5 \mathrm{Ma}$, which are broad and shallow (Figure 5), also suggest abundant magma supply, perhaps associated with the hotspot as it was approaching the ridge axis from the west.

No migrating offsets initiated at the southern triple junction to straighten the ridge axis. The southern section of the Pacific-Galapagos EPR straightened when the triple junction stabilized and migrated south during the formation of wedges V1 and V2 (Figures 7 and 8). Since about $0.1 \mathrm{Ma}$, the rapid northward motion of the triple junction has resulted once again in an obliquely oriented ridge axis $\left(338^{\circ}\right.$ rather than $\left.353^{\circ}\right)$, similar to the oblique orientation which developed $\sim 1.5 \mathrm{Ma}$ when the southern triple junction was jumping north. The recent stabilization of the triple junction at Dietz volcanic ridge may now be straightening the axis as the triple junction migrates southward.

We have addressed several outstanding problems at the Galapagos triple junction, but several remain. For example, we have yet to explain why the C-N Rift increased its propagation rate and its tip moved closer to the EPR at 1.5 Ma. The decrease in distance between the tip and the ridge axis occurred during the time that the proposed hotspot was approaching the EPR from the west and thus, it is possible that the hotspot played a role in perturbing what appears to have been a stable configuration for several millions of years.

We also have not been able to constrain the origin of the rotated section of crust in the northeast section of the Galapagos microplate first identified by Lonsdale (1988). Rotation must have occurred prior to the establishment of the southern boundary of the microplate, since remnants of the rotated seafloor are observed within Dietz rift basin, and portions of the rotated abyssal hills are covered by lava flows presumably from the hotspot. The western edge of the rotated section of crust is sharp, possibly cut by the rapid southward migration of the EPR offset that occurred at about $1 \mathrm{Ma}$. There is no evidence on the Pacific plate, however, of the remnant that would have been cut off as the offset migrated south.

And finally, since the Galapagos microplate is not rotating with a high angular velocity as has been proposed in earlier work (Klein et al., 2005; Schouten et al., 1993), we do not understand how extension on its southern boundary is transferred to the C-N Rift. Lonsdale (1988) proposed that there was transform motion on the southern scarp of C-N Rift bordering the microplate as indicated by an earthquake focal mechanism in the region of the scarp (Figure 4b). Future bathymetry and seismic data collected over the C-N Rift in this region may provide additional clues. As of now, this question remains unanswered.

\section{Conclusions}

Newly identified traces on the Pacific plate of two triple junctions, one north and one south of the projected tip of the C-N Rift, provide strong evidence that the succession of transient rifts observed on the Nazca and Cocos plates formed true RRR triple junctions with the EPR, and validates the use of the crack interaction model to explain the complex topography in this region. According to the model, transient rifts are generated by stresses associated with the tip of the propagating C-N Rift which remains separated from the EPR (Mitchell et al., 2011; Schouten et al., 2008; Smith et al., 2011).

The southern triple junction trace on the Pacific plate helps to elucidate the development of the southern boundary of the Galapagos microplate at $\sim 1.4 \mathrm{Ma}$. Before this time, we propose that a hotspot was approaching the southern triple junction from the west. Extension became 
fixed on the 1.4 Ma transient rift to form the South scarp of the future Dietz rift basin. NazcaGalapagos magmatic spreading was initiated at the triple junction at a rate of $\sim 39 \mathrm{~mm} / \mathrm{yr}$, and lavas flooded the area north of the South scarp. At $\sim 1.25$ Ma the hotspot crossed from the Pacific to the Nazca plate and shortly thereafter, Dietz seamount began to build within the young NazcaGalapagos spreading center near the triple junction. A system of dikes was emplaced into Dietz rift basin and eruptions built volcanic ridges several hundreds of meters in relief.

At $\sim 0.8 \mathrm{Ma}$ the triple junction and magmatic spreading jumped north, opening at a rate of $\sim 33 \mathrm{~mm} / \mathrm{yr}$. The early phase of magmatism in the eastern section of the microplate boundary was followed by amagmatic extension on the North scarp of Dietz rift basin. Most recently ( 0.1 Ma) magmatic spreading has jumped north to Dietz volcanic ridge, and seismicity indicates northwest-southeast extension on the North scarp. Northward jumping of the triple junction has maintained its location, and the southern boundary of the microplate, west of the proposed hotspot.

The shape of the Pacific-Galapagos EPR responded to rapid changes in the triple junction locations. About 1.5 Ma, the shape of the EPR between the two triple junctions became convex westward in plan view. We hypothesize that the north and south ends of the axis bent eastward to main contact with the triple junctions which were jumping rapidly toward the $\mathrm{C}-\mathrm{N}$ Rift at that time. Two southward migrating offsets nucleating at the northern triple junction at 1.0 and 0.6 Ma straightened the axis in the north. The southern section of the EPR straightened when the triple junction stabilized and migrated south.

The Galapagos triple junction region is complex, but it is this complexity that provides an opportunity to advance our understanding of Earth's lithospheric plates and mantle. In this unique region we are obtaining a better understanding of how plates deform internally near plate boundaries and the relationship between this deformation and upwelling mantle material.

\section{Acknowledgments}

We would like to thank the captain, crew, and the shipboard technical support group of the $\mathrm{R} / \mathrm{V}$ Atlantis for their effort to collect the best multibeam data possible. We also thank J. Cann for many fruitful conversations and C. Holly for quantifying lineations in the triple junction region using GIS software. DKS was partially supported by NSF grant OCE-1028537, WZ by NSF grant EAR-1056317, and LM by NSF grant OCE-1060878.

\section{References}

Argus, D.F., Gordon, R.G., and DeMets, C., 2011, Geologically current motion of 56 plates relative to the no-net-rotation reference frame: Geochem. Geophys. Geosyst., v. 12, p. Q11001.

Bird, P., 2003, An updated digital model of plate boundaries: Geochemistry, Geophysics, Geosystems, v. 4, p. 10.1029/2001GC000252.

DeMets, C., Gordon, R.G., Argus, D.F., and Stein, S., 1994, Effect of recent revisions to the geomagnetic reversal time scale on estimates of current plate motions: Geophys. Res. Letts., v. 21 (20), p. 2191-2194. 
Fox, C.G., Matsumoto, H., and Lau, T.-K., 2001, Monitoring Pacific Ocean Seismicity from an Autonomous Hydrophone Array: J. Geophys. Res., v. 106, p. 4183-4206.

Gripp, A.E., and Gordon, R.G., 2002, Young tracks of hotspots and current plate velocities: Geophysical Journal International, v. 150, p. 321-361.

Klein, E.M., Smith, D.K., Williams, C.M., and Schouten, H., 2005, Counter-rotating microplates at the Galapagos triple junction, eastern equatorial Pacific Ocean: Nature, v. 433, p. 855858.

Lonsdale, P., 1988, Structural patterns of the Galapagos Microplate and evolution of the Galapagos triple junction: J. Geophys. Res., v. 93, p. 13551-13574.

_, 1989, The rise flank trails left by migrating offsets of the equatorial East Pacific Rise axis: J. Geophys. Res., v. 94, p. 713-743.

Lonsdale, P., Blum, N., and Puchelt, H., 1992, The RRR triple junction at the southern end of the Pacific-Cocos East Pacific Rise: Earth Planet. Sci. Letts., v. 109, p. 73-85.

Mitchell, G.A., Montési, L.G.J., Zhu, W., Smith, D.K., and Schouten, H., 2011, Transient rifting north of the Galápagos Triple Junction: Earth Planet. Sci. Letts., v. 307, p. 461-469.

Schouten, H., Klitgord, K.D., and Gallo, D.G., 1993, Edge-driven microplate kinematics: J. Geophys. Res., v. 98, p. 6689-6701.

Schouten, H., Smith, D.K., Montési, L., Zhu, W., and Klein, E.M., 2008, Unstable Northern Rifts of the Galapagos Triple Junction, Eastern Equatorial Pacific: Geology, p. 330-342, doi:10.1130/G24431A.1.

Schouten, H., Smith, D.K., Zhu, W., Montesi, L.G., Mitchell, G.A., and Cann, J.R., 2009, Transient cracks and triple junctions induced by Cocos-Nazca propagating rift: Eos Trans. AGU, v. 90(52), Fall Meet. Suppl., p. Abstract T51A-1491.

Searle, R.C., and Francheteau, J., 1986, Morphology and tectonics of the Galapagos Triple Junction: Mar. Geophys. Res., v. 8, p. 95-129.

Smith, D.K., 2011, Grid(s) of multibeam bathymetry at Galapagos Triple Junction: Integr. Earth Data Appl., v. Palisades, New York, , p. doi:10.1594/IEDA/100005.

Smith, D.K., Schouten, H., Zhu, W., Montési, L., and Cann, J.R., 2011, Distributed deformation ahead of the Cocos-Nazca Rift at the Galapagos Triple Junction: Geochem. Geophys. Geosyst., v. 12, p. doi:10.1029/2011GC003689.

Wilson, D.S., Hey, R.N., and Nishimura, C., 1984, Propagation as a mechanism of reorientation of the Juan de Fuca Ridge: J. Geophys. Res., v. 89, p. 9215-9225.

Zonenshain, L.P., Kogan, L.I., Savostin, L.A., Golmstock, A.J., and Gorodnitskii, A.M., 1980, Tectonics, crustal structure and evolution of the Galapagos triple junction: Mar. Geol., v. 37, p. 209-230.

\section{Figure Captions}

Figure 1. Multibeam bathymetry over the Galapagos triple junction region (Smith, 2011). Black lines: ridge axis and traces of the triple junctions on the Cocos and Nazca plates (Schouten et al., 2009). EPR: East Pacific Rise; TJ: current triple junctions at $2^{\circ} 40^{\prime} \mathrm{N}$ and $1^{\circ} 10$ 'N; IR: Incipient Rift the current northern triple junction; GMP: Galapagos microplate.

Figure 2. Lineation map of the Galapagos triple junction region. Lines identified by eye from the map in Figure 1. Thick black lines: ridge axes and traces of the triple junctions on the Pacific, Cocos, and Nazca plates. The Cocos plate triple junction trace from Schouten et al. 
(2009) is shown on the Pacific plate and fits the seafloor patterns remarkably well. There is notable symmetry in the triple junction traces between about 2.5 and $1.5 \mathrm{Ma}$, after which the Galapagos microplate forms. EPR: East Pacific Rise; IR: Incipient Rift; GMP: Galapagos microplate. Boxes mark the regions shown in Figure 3.

Figure 3. Bathymetry on the Pacific plate for (a) the northern triple junction trace, and (b) the southern triple junction trace. Thin black lines indicate lineation directions. Thick black lines show the ridge axis and triple junction traces. Circles present the azimuths of the abyssal hills that meet at some of the paleo triple junctions. Azimuths of the abyssal hills are shown at the top of the circle; the area between the abyssal hill orientations is shaded and the angle between them is shown at the bottom. The location represented by each of the circles is marked along the trace.

Figure 4. Detailed view of the southern triple junction. Black lines: spreading axes and the triple junction traces on the Pacific and Nazca plates. The triple junction trace on Nazca crust $<1.5 \mathrm{Ma}$ was obtained by combining evidence on the Pacific and Nazca plates. Dashed line on the Galapagos microplate: intersection of northwest-southeast oriented volcanic ridges with Pacific-Galapagos EPR abyssal hills. (a) Multibeam bathymetry with thin black lines indicating lineation directions. (b) White circles: hydrophone recorded seismicity (Fox et al., 2001). Beach balls: focal mechanisms obtained from the Global Centroid-Moment-Tensor (CMT) Project (http://www.globalcmt.org/). V1 and V2: consecutive wedges of seafloor formed after rapid jumping of the southern transient rifts ceased. c) Plate velocity triangles for V1 and V2 using opening directions and velocities for Pacific-Nazca from NUVEl-1A (DeMets et al., 1994).

Figure 5: The Pacific-Galapagos EPR. Black lines: spreading axes and triple junction traces. Black dashed lines: pseudofaults of two southward migrating offsets initiating at the northern triple junction. Thin black lines: rotated plateaus generated between the overlapping limbs of the EPR at the offset. Black line marked A-B marks the location of the profile shown. Note the transition in character of the abyssal hills, which occurs at about $1.5 \mathrm{Ma}$. They become broader and shallower, and in plan view their northern and southern ends curve eastward.

Figure 6. Profiles across the EPR near the Galapagos triple junction. Horizontal lines on the profiles indicate a water depth of $3200 \mathrm{~m}$. Regions shallower than $3200 \mathrm{~m}$ are filled. North of the current offset of the EPR at $1050^{\prime} \mathrm{N}$, the axis is deep with horst and graben morphology similar to a slow-spreading mid-ocean ridge. Immediately south of the offset, the ridge axis is broad and shallow.

Figure 7. History of proposed hotspot. The EPR and triple junction traces are marked by black lines on the multibeam data. V1 and V2: consecutive wedges of seafloor formed after rapid jumping of the southern transient rifts ceased at about 1.4 Ma. Thick black lines show the motion of the proposed hotspot with respect to the Pacific and Nazca plates. Hotspot motion was estimated using NUVEl-1A (DeMets et al., 1994) and HS3-NUVEL-1A (Gripp and Gordon, 2002). Black circle: location of Dietz seamount. Red circle: current location of the proposed hotspot.

Figure 8. Cartoon showing the hypothetical development of the southern boundary of the Galapagos microplate. Note that the panels are not separated by a constant time interval. Double lines: spreading centers. Lines with hachures: scarps. Active scarps and spreading axes are shown by black lines. Gray indicates dead or dying spreading axes and scarps, and old flows. 
Arrow heads show direction of opening. Large gray circle: proposed hotspot. Small black circle: Dietz seamount, which still might be active. 1.4 Ma: The hotspot approaches the EPR; extension is fixed on the South scarp; lavas flood the area north of the scarp. 1.2 Ma: The hotspot has crossed to the Nazca plate; Dietz seamount forms within the young Galapagos-Nazca spreading center (V1). 0.7 Ma: Magmatic spreading has jumped north to V2; amagmatic extension to the east is on the North scarp of Dietz rift basin. 0.15 Ma: Magmatic spreading on V2 continues. 0.1 Ma: Magmatic spreading jumps north to Dietz volcanic ridge. Present: Magmatic spreading continues on Dietz volcanic ridge; amagmatic extension continues on the North scarp. The EPR's current configuration is shown in the Present panel. In all other panels, it is schematic. 


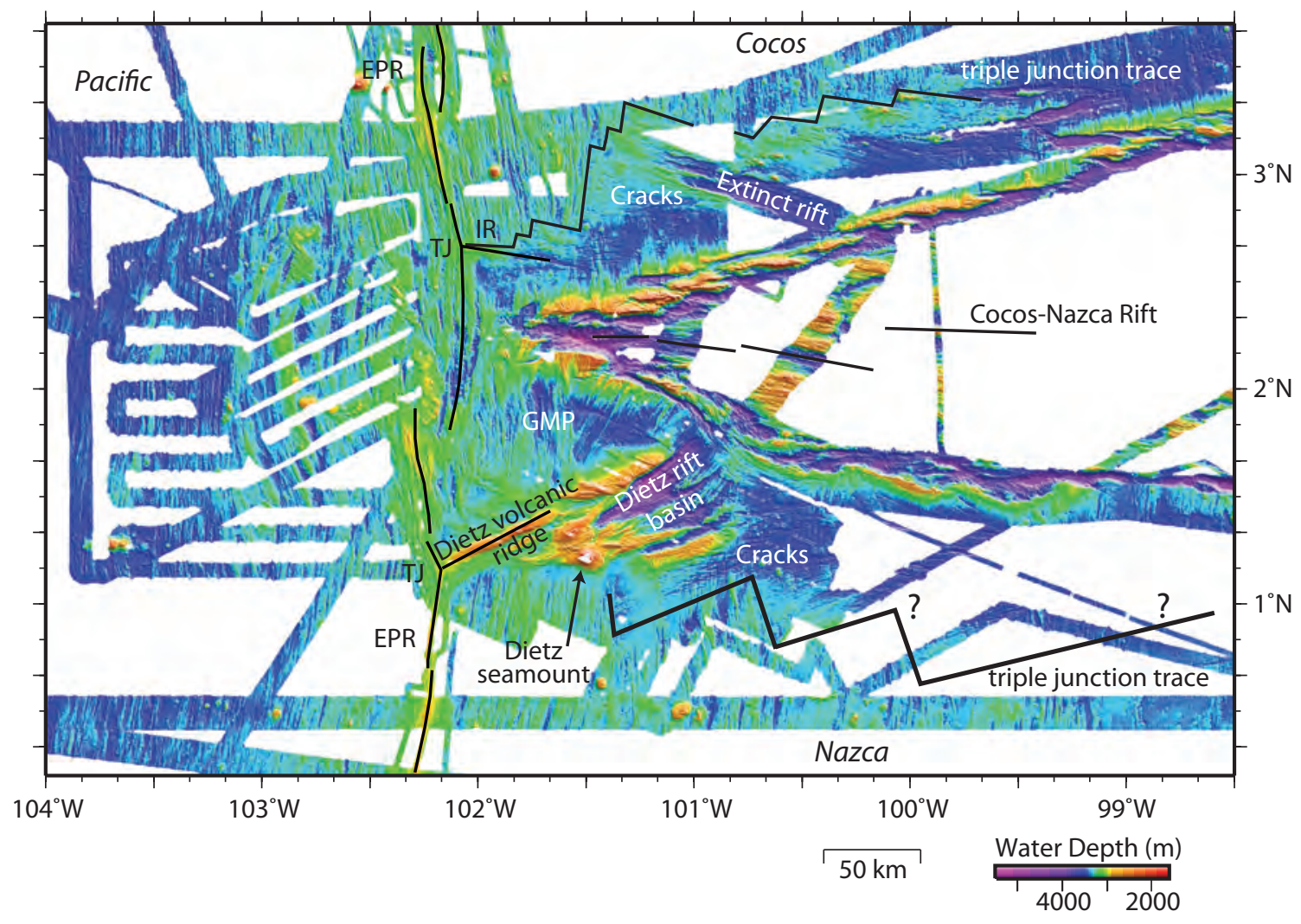

Figure 1 


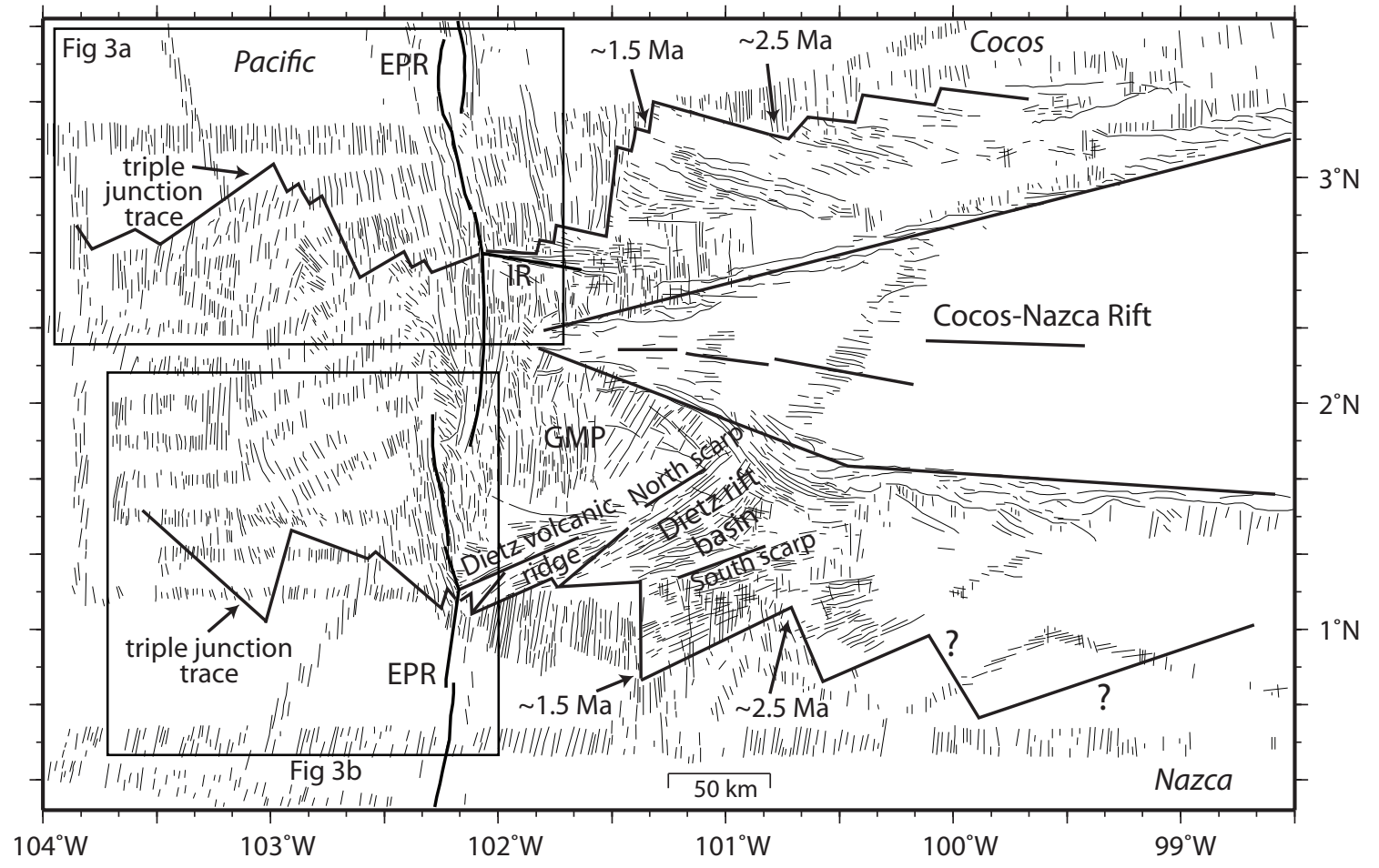

Figure 2 
a) $-103^{\circ} 30^{\prime}$

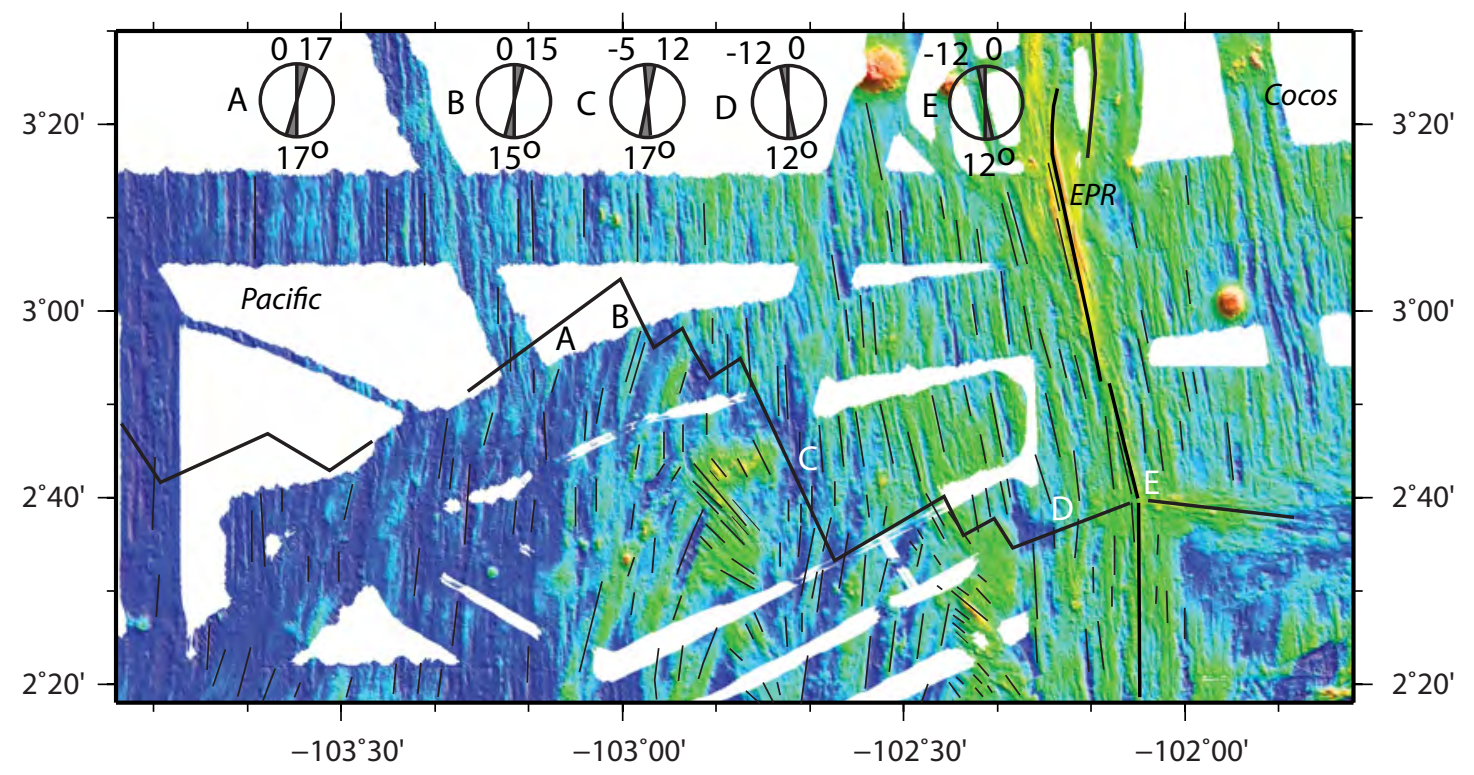

b)

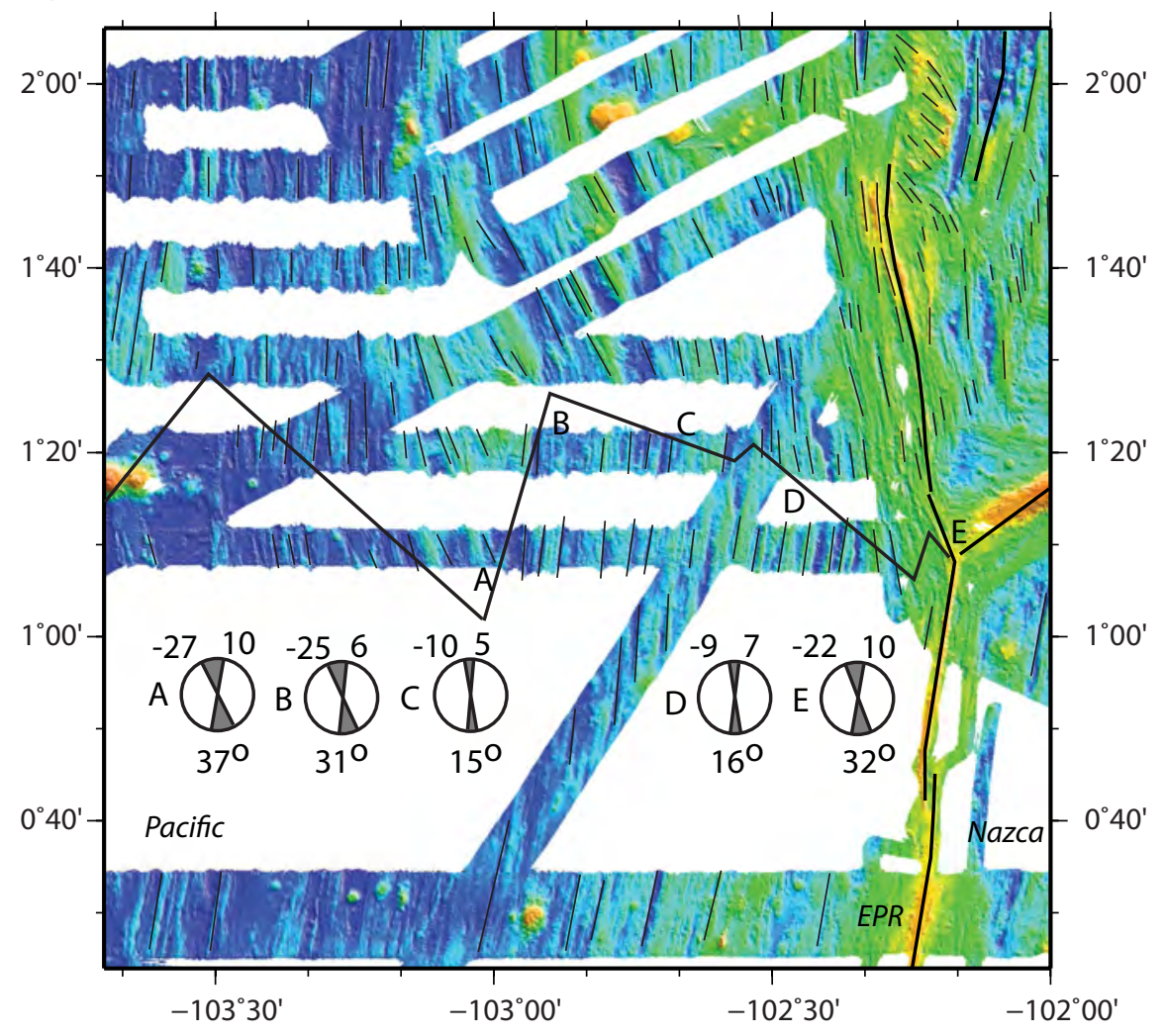

Figure 3 

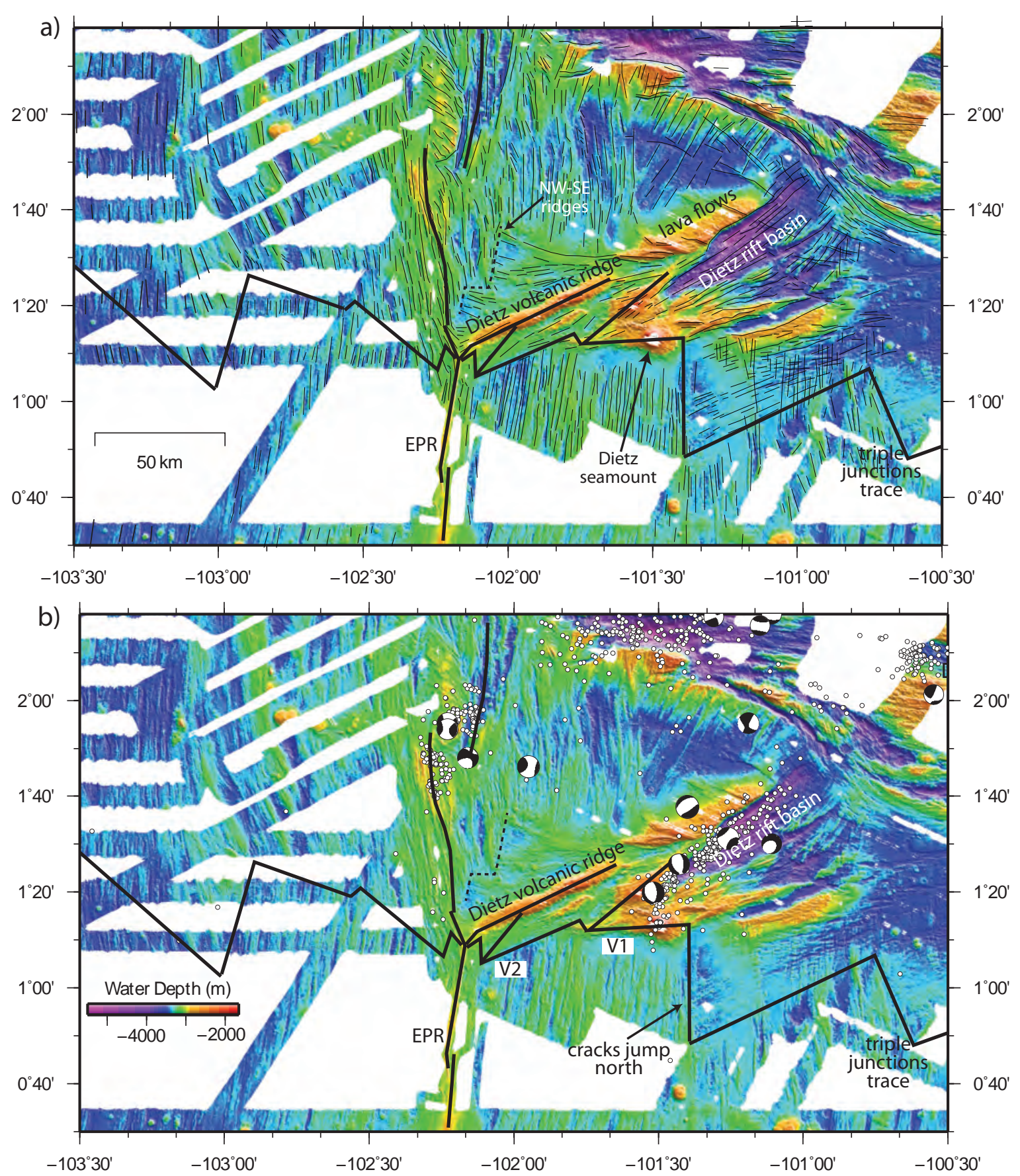

C)

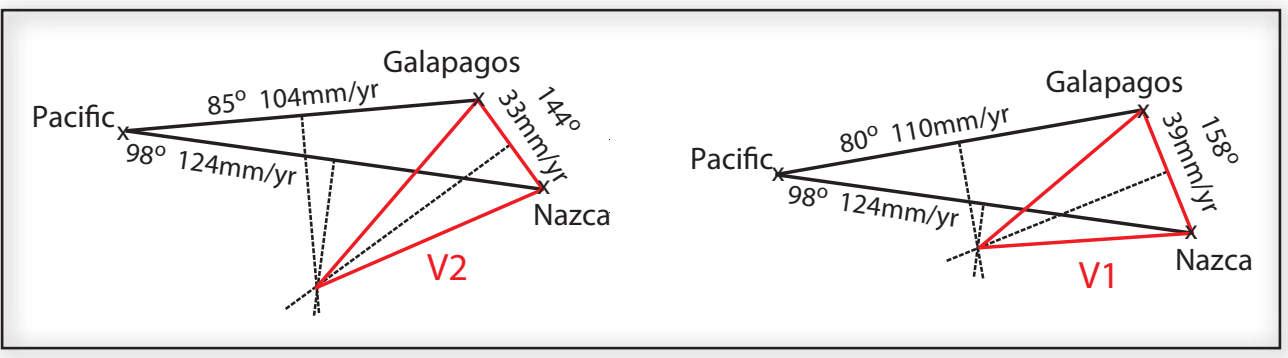

Figure 4 


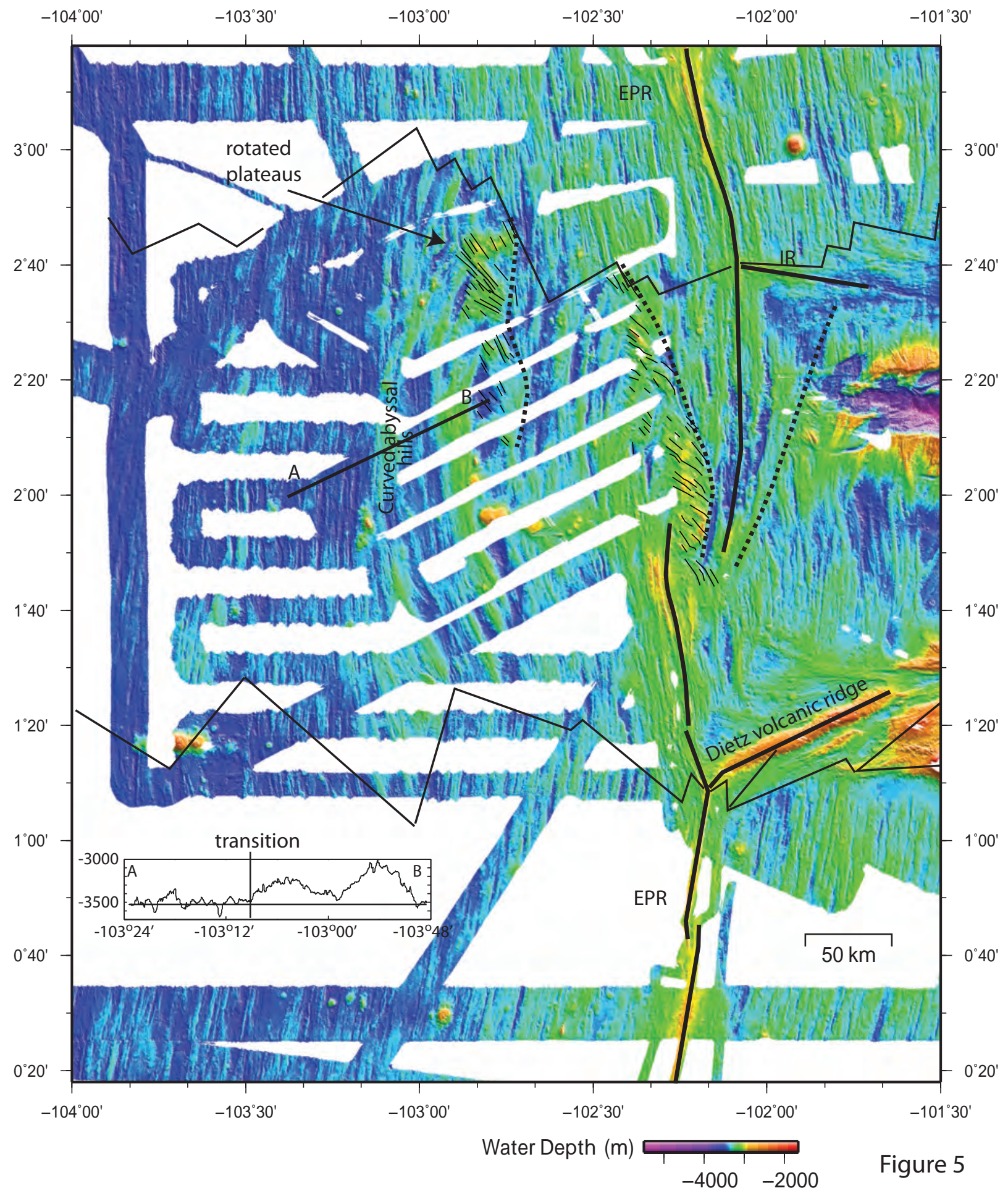




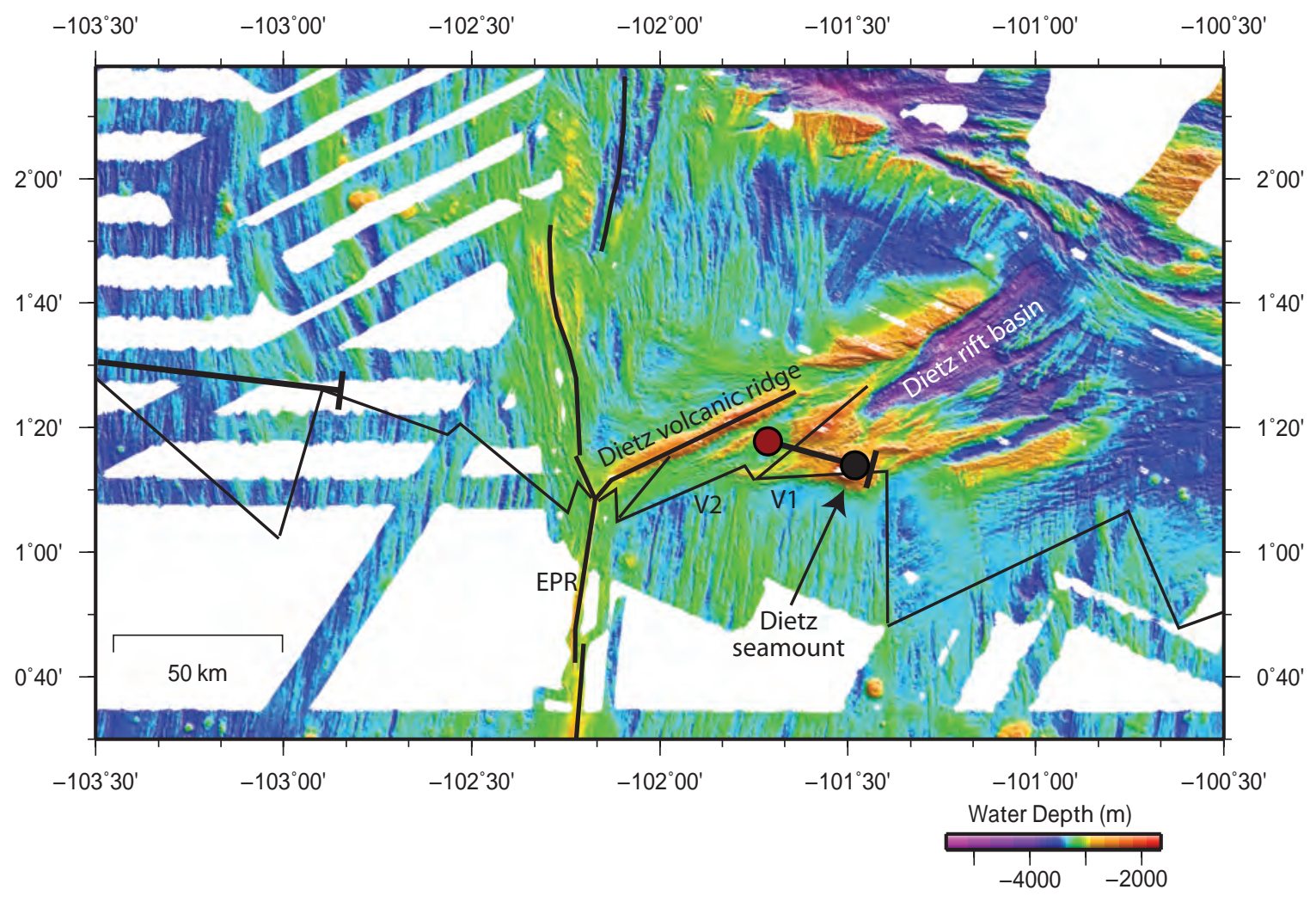

Figure 7 

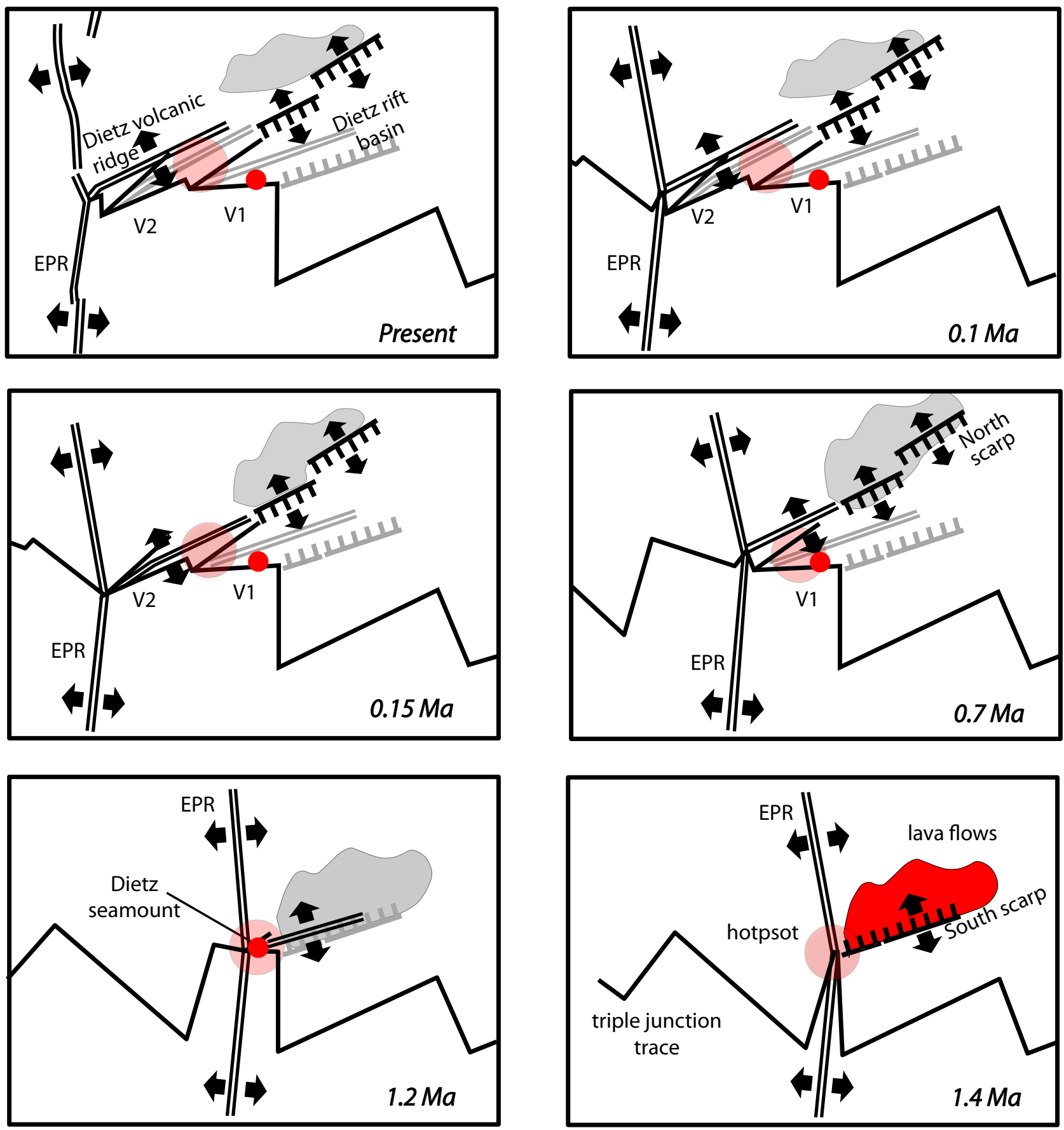

Figure 8 